\title{
China in Africa: A Partner or Patron Ethiopia in Focus
}

\author{
Gashaw Ayferam Endaylalu \\ Wollo University, Dessie, Ethiopia
}

\begin{abstract}
This study examined Africa-China relation by taking the post-1991 Sino-Ethiopia relations as a case study, in light of patron-client relationship. Methodologically, the study employed qualitative research methodological approach and case study research design. Accordingly, the study has used secondary source of data collected from books, journal articles, government reports, and other pertinent internet sources. Given the data gathered are qualitative; the study employed qualitative data analysis techniques specifically document and discourse analysis. The findings of the study show that although both countries evoked the rhetoric altruistic principles of strategic partnership, mutual benefit and win-win cooperation, Ethio-China relation is asymmetrical. Party-to-party relations is more apparent and thus from the Ethiopia aspect, regime sustenance is prior agenda than State sustenance and interest. This foreshadows patron-clientelism. This study, therefore, suggests the need of pragmatic engagement and adoption of countering strategy of patronage and "clientelism”. Falling to do so would mean blessing "clientelism".

Keywords: patron-client, development partner, China, Africa, Ethiopia
\end{abstract}

\section{Introduction}

African-China relations have evoked much discussion and become a contentious issue in contemporary literatures. Although the relation of China with Africa dates back to ancient times, the year 1950's was the turning point of their relation (Gedion \& Mathews, 2010). Since 1950's the Sino-African relation was turbulent and it was on the eve of end of Cold War that Africa and China vividly entered into a new relations.

In the aftermath of the end of Cold War, China pays high attention to the continental Africa (Fantahun, 2013). Since then China engagement in Africa is unprecedented. The multifaceted and the very contentious China-Africa relation began to be studied since the "rise of China" in Africa and particularly since the end of the Cold War. While much of current scholarship has been preoccupied with China's deepening presence in Africa and the threat, this poses to Western interests in the continent (Dijk, 2009), Chinese as a new colonizer or partner (Fantahun, 2013), the motive of China in Ethiopia (Seifudein, 2012); the debates have failed to situate and view China-Africa, in particular China-Ethiopia, relations in light of patron-client relations. Likewise, Tegegne (2007) studies the impacts of Chinese imports on domestic producer largely from economic point of view. As well, Gofie and Venkataraman (2015) examined Ethio-China trade relations from economic sphere. These aforesaid studies neglected the interplay of politics and economics. Thus, the departure of this study is that the politico-economic relation of and "political game" between Ethiopia and China can be understood in light of patron and client. Thus, earlier studies give only scant attention and overlook an important insight and in turn leave deficiency in the available literature. Thus, it is the intention of this study to

Gashaw Ayferam Endaylalu, lecturer, Department of Political Science and International Relations, College of Social Science and Humanities, Wollo University, Dessie, Ethiopia. 
examine Africa-China relation, Ethiopia as a case study, in light of patron-client relationship.

To this end, the study has eight parts. The first part is introduction. The second is a conceptual analysis. The third part depicts Ethio-China historical relations. The fourth and fifth parts examine Ethio-China relations in light of patron-client relations. The sixth and seven parts are about the challenges and prospects of Ethio-China relations. Final, the paper has concluding remarks.

\section{Patron-Client Relationship: A Conceptual Framework}

This paper's analysis of Ethio-China relations is contextualized by patron-client relationship approach. It is conventionally believed that patron-client relationship and inter-state relations are oxymoron. Nevertheless, patron-client relationship may be used as an analytical tool beyond intra-state relations. Although contemporary literatures, most often, treat patron-client relationship as synonymous with "patrimonialism", for the purpose of this paper, patron-client relationship can be defined as an asymmetric relation, reciprocal exchange of benefits and as a "give- and take- relations". According to Fukuyama (2014, p. 59), "a patronage relationship is a reciprocal exchange of favors between two individual of different status and power, usually involving favors given by the patron to the client in exchange for the client's loyalty and political support”. Although Fukuyama's definition of patronage and other scholar's (Szeftel, 2000; Kiser \& Sacks, 2011) theoretical literature focuses primarily on intra-state "clientelism", the model is an important insight to examine the relations of highly unequal and asymmetrical inter-state relations. Lyons (1986), for instance, goes beyond the conventional meaning of patron-client relations and he used patron-client relations as a unit of analysis in examining Ethio-U.S. relations. Thus, it is possible to examine asymmetrical inter-state relations in light of patron-client relationship. In inter-state relations, patron-client relationship may be manifested through the provision of material support, aid, unconditional loans and protection from the stronger state (the patron state) and reciprocally a degree of deference, access to resource, political and ideological support from its weaker partner (the client state) (Ciorciari, 2013). Consequently, this asymmetric and reciprocal relation may erode the sovereignty and autonomy of the so-called "client state".

In this regard, the "rise of China in Africa” led scholars and politicians to warn African leaders to counter the danger of patron-client relationship between China and African countries. Particularly in Western discourse, China is regarded as a new-colonizer of Africa, new imperialist and new-mercantilist. For instance, Yan and Barry (2007), in their studies of the "China-in-Africa discourse”, used the title "The Forest for the Trees" to illustrates reciprocity in Sino-African relations. Likewise, A New York Times Editorial, as cited in (Zeleza, 2008, p. 175; Yan \& Barry, 2007, p. 9) used the title "Patron of African Misgovernment" to depict China-Africa relations. Moreover, this suspicion and danger has been official notified by U.S. president Barack Obama $^{2}$ by saying “So many Africans have told me... We don’t want patrons; we want partners who help us build our own capacity to grow". Thus, his speech foreshadows the existent of a patron-client relation between Africans and others be it China or other Western countries. Thus, it is the central objective of this paper to examine whether China is a development partner or a patron of Africa in general and Ethiopia in particular.

\footnotetext{
1 This indicates that the "Forest" which symbolizes China-a dominant and central figure-protects the tress and; the tress-countries of Africa-also reciprocally supports the China.

2 Obama's speech to the people of Africa at the African Union Headquarters on July 28, 2015. Accessed September 2016 from https://obamawhitehouse.archives.gov/the-press-office/2015/07/28/remarks-president-obama-people-africa.
} 


\section{The Genesis of Ethio-China Relations: A Historical Perspective}

Though there is no consensus among historians and scholars about the initial contact of China and Africa, Sino-Africa relations have ancient roots ${ }^{3}$. Although Sino-Africa relation can be traced back to ancient times, it was the Bandung Conference ${ }^{4}$ of 1955 which was marked as a watershed in Sino-African in general and Sino-Ethiopian relations (Dent, 2011; Lumumba-Kasongo, 2011). Following the conference, China sent Chinese People's Cultural and Art Delegation to African countries including Ethiopia (Wei, 2011). In these earlier periods, though China was perceived as "Other" due to ideological reason, Ethio-China relations has undergone and opened a new chapter. During the imperial regime of Ethiopia, China denounces the Fascist invasion. Ethiopia, on its side, abstained from voting to China in the quest of admission to the UN as a sole representative of all the Chinese people. However, Ethiopia voted later for Chinese (Shinn, 2014).

Despite such progress, Ethio-China relations during the imperial period was an up and down relations. Moreover, Chinese and Ethiopia interest in international issues had also been different, if not contradictory. The USA interest in the horn of Africa and its amicable relation with the imperial Ethiopian government on one side and the establishment of China-Somalia diplomatic relations, and the signing of the a protocol for economic and technical cooperation between China and Somalia in 1969-all in all contributed for the delay of official diplomatic relations between China and Ethiopia (Wang, 2014; Wei, 2011). Though there were some kinds of relations between the two countries, diplomatic relationship was only established in 1970.

In 1974 the military council, Derg, came to power via revolution. Thus, the regime change in Ethiopia has its own repercussion for the government at Beijing. Although amicable relations have been manifested in the aftermath of the coming power of the Derge regime, their relations were eroded as of 1976 and 1977 due to Chinese support for Somalia and Ethiopian alliance with the Soviet Union (Shinn, 2014). Thus, China-Ethiopian relations both under the imperial and military Derg regime were problematic due to the domestic, regional, and international conditions or simply because of the interplay of domestic and international politics.

In 1991 Ethiopian People's Revolutionary Democracy Front (EPRDF) came to power by overthrowing the military Derg regime. China has become a new partner of the Ethiopia's new government. Different factors contributed for this new relation: (a) to gain international recognition and support, (b) the need of socio-economy recovery thru foreign assistance, (c) Chinese motif to return to Africa, (d) Chinese as an alternative of Western countries (Shinn, 2014). Thus, due to these reasons, the new Ethiopian government regarded China as the best candidate for future economic relations. Their relations have reached climax level with the visit of the late Prime Minister Meles Zenawi to China in 1995 and reciprocated by the president Jiang Zemin of China who visited Ethiopia in 1996 (Wang, 2014; Wei, 2011; Fantahun, 2013). Therefore, the year 1995 was a watershed because this was the period which marked the beginning of a new dimension of Ethio-China bilateral relation. Ethiopia-China relations also strengthened with the launch of Forum on China-Africa Cooperation (FOCAC) which was held in Beijing. In this regard, Ethiopia organized the second ministerial conference of FOCAC in 2003 in Addis Ababa (Fantahun, 2013). In view of that, from Chinese

\footnotetext{
${ }^{3}$ For Dent, Sino-African relations traced back to the 10th century BC and there was a bilateral trade between Alexandria, city of Egypt and China. In contrast, Lumumba-Kasongo traced China’s first contact with Africa as old as the Ming Dynasty in the 15th century.

4 The Bandung Conference was an Asian-African summit held in April 1955. The conference was attended by 29 countries of which six countries were from Africa; Egypt, Ethiopia, Gold Coast, Liberia, Libya, and Sudan.
} 
perspective, Ethiopia is seen as a unique partner. However, in reality China used Ethiopia as means to an end.

\section{China as a Development Partner of Ethiopia}

Scholars regarded the growing engagement of China in Africa as predominantly obsessed by resource for its growing economy and a market for its manufactured goods. Taylor (2006) contends that the key Chinese interest in Africa is resource particularly oil. Similarly Corkin (2008) stated that the underlying motives for current Chinese growing engagement in Africa is the growing need for raw materials and oil to feed China's burgeoning economy. Thus, for most of, if not all, Western analysts, the main driving force behind China's involvement in Africa is for natural resources and thus, China focuses on a few resource hubs African countries. However, China has a growing relation with non-resourceful African countries such as Ethiopia. Ethio-China relations have been growing with unprecedented degree since 1995 (Fantahun, 2013). The increasing role of China in Ethiopia and the growing tendency of Ethiopia towards China have its own ground. Thus, China in Ethiopia - why China in Ethiopia?-may depict a new insight in identifying the lust of China in Africa.

On both sides, their relationship is motivated by economic, diplomatic, strategic, and ideological considerations. Both have their own intrinsic goals to be achieved, though their relation is asymmetrical. According to Gedion and Mathews (2010), the growing propensity of Ethiopia towards China is due to economic assistance, alternative partner to the West and role model. Cabestan (2012) also contends that for Ethiopia, "partnership with China mainly serves the internal political and economic purposes of the regime that has been in place since 1991” (p. 52). First, the growing involvement of China is an opportunity for Ethiopia in the areas of foreign aid, loans, and investment. In this regard, China is providing aid, credit finance, unconditional loan, and also debt reduction without any politico-economic requirements to be fulfilled by Ethiopia. Second, Ethiopia regarded China as an alternative to the Western powers. Third, Ethio-China relation is more of pragmatic (Shinn, 2014; Gedion \& Mathews, 2010). Both countries underlined altruistic principles such as solidarity, cooperation, mutual benefit as the core guiding principles of their relations. Moreover, China has been providing direct aid in building projects and offering scholarships for Ethiopian students to study in China. Although some regarded the rise of China in Africa as a new wave of colonialism where African countries supply their raw materials to China while the latter sends its manufactured goods to Africa, Ethiopia is not as such a resource full country as compared to other resource endowed African countries. Thus, why China in Ethiopia? What is the very lust of China in Ethiopia if its interest driver is resource?

For China, Ethiopia is in its list of strategic partner. First, Ethiopia's vital role in Africa political history and its strategic location as the seat of Africa Union, United Nations economic commission for Africa, different international and regional organizations, and diplomatic missions-all make Ethiopia a potential candidate to be a strategic ally and partner of any external actors in the continent (Seifudein, 2012; Gedion \& Mathews, 2010). Thus, Ethiopia, a country being the diplomatic capital of Africa, is well situated for a country like China to influence the continent. Without doubt, Chinese growing relations with Ethiopia, the diplomatic hub and water tower of African country, has a symbolic significance for the government at Beijing. Second, Chinese quest for raw material particularly oil is one driving force of China in Ethiopia. Third, China interest in Ethiopia as elsewhere Africa is to halt the diplomatic relation between African countries and Taiwan and in turn to get the support of African countries for its "One Chain Policy” (Shinn, 2014; Gedion \& Mathews, 2010). Thus, for China, economic and trade cooperation with Ethiopia is not an end in itself rather it is viewed as a means. 


\section{Is China a Patron?}

The presence of China in Africa is the subject of different and varying interpretations. Contemporary scholarship illustrates China as neo-colonialist and new imperialist. For instance, New York Times in 2007 (as cited in Zeleza, 2008, p. 175) describes China as "Patron of African Misgovernment". Another study (Assogbavi, 2010) also portrays China as Sudan’s, particularly the ruling National Congress Party’s, key patron during the Darfur crisis. Thus, historically, a patron-client relation is not new in Sino-African relations. In this regard, Ethiopia is not exceptional rather there exist complex relations between China and Ethiopia. Do patron-client relations depict such relations? Is there any foreshadow impetus of patron-client relations? These are the core questions of this paper. Although the engagement of China in Ethiopia is not new, the scope, scale, and area of post-1991 Chinese involvement in Ethiopia is unprecedented. Since 1995, China has broadened its relationship with Ethiopia in numerous areas: aid, finance (loan and grant), investment, trade, development assistance, technology transfer, training and education, and cultural exchange. Despite the rhetoric "altruistic principle” of equality, held by both countries political leaders, the underlying conditions are highly asymmetrical (Seifudein, 2012). From China perspective, Ethio-China relation is win-win cooperation, however their relation and engagement is far from win-win. Thus, their relation remains asymmetrical and very complex.

Such asymmetrical relations may have a danger of patron-client relations. One distinct features of patron-client relation is that the relationship occurs between actors of unequal power and status, and it is also based on the principle of reciprocity (Ciorciari, 2013). In this regard, there is a foreshadow impetus of a patron-client relationship in the contemporary Africa-China in general and Ethio-China relations in particular. First, reciprocity is manifested in Sino-African relations. The government of China has been increasingly encouraging Chinese corporations to play a role in broad Sino-Africa ties. Reciprocally this empowers China to maintain its commercial and political links with African countries. An important "spin-off" of this is to create a patron friends and adherents which will give both moral and political support to their patroniser within the international system. On the side of China, it is the very lust of China to have African countries as a counterbalance strategy against the U.S. global hegemony. On the side of African countries including Ethiopia, absence of political conditionality and aid either in the form of grant or loan would enable the ruling elite to consolidate their power and in turn to ensure their life presidency and engage in administrative mal-practice. Though African countries have friendly relations with China, the Ethiopia case is different, if not similar. Ethiopia particularly the government is perceived as a friend of Beijing in a special way. In the views of Chinese political leaders, the late Prime Minister Meles Zenawi, who said in 2006 FOCAC, "China is not looting Africa”, was regarded as an effective expositor and even defender of China as a model and partner for Africa (Seifudein, 2012). Thus, their relation is a form of "tit for tat". Second, the observed intimacy and intense political relations between political elites in China and numerous African countries may have a danger of patron-client relations. This is particularly true in Ethio-China relations. One of the elements which underpin Ethio-China relation is party-to-party relations. Although China and Ethiopia are different in ideology, they are similar in practice. Not surprisingly, EPRDF and Chinese communist party (CCP) have a strong relation (Shinn, 2014; Lejeune, 2015). They have also signed a memorandum of understanding on Exchange and Cooperation between the CPC and EPRDF in 2010. CCP also sent delegations to the EPRDF's Organizational Conferences in 2008, 2010, and 2013. Moreover, Ethiopia also learns the media practice of China which is totally against 
freedom of press (Lejeune, 2015). Realistically speaking, Ethiopian's media practice is a carbon copy of Chinese ${ }^{5}$.

Shinn (2014) stated that "China provides technical assistance and jamming equipment to help Ethiopia's Information Security Network block signals from anti-government radio stations and, from time to time, the Amharic-language programs of the Voice of America and Deutsche Welle” (p. 11). On the side of China, CCP promised to extend the CCP's support in party capacity building, leadership skill training, and experience sharing in various areas. In reciprocity, the Ethiopian Parliament passed a resolution in support of Chinese Anti-Secession Law in 2006 (p. 11).

China looked Ethiopia and also African countries as a way to ward off Western criticism of its human rights record by maintaining a patron friend. On Ethiopia side, EPRDF uses China as a fortress against criticism and disavowal of the West. This is clearly manifested in the aftermath of the 2005 Ethiopian general election ${ }^{6}$. While the Western criticized the ruling party, China became the major trading partner of Ethiopia (Seifudein, 2012). Thus, party-to-party relations are another manifestation of patron-client relations. And such party-to-party relation may pose a patron-client relation. Moreover, the asymmetric relations may unintentionally become a patron-client relation, at least in the near future.

\section{Challenges of Ethio-China Relations}

Ethio-China relationship has been growing with unprecedented degree. However, their relationship is not without difficulties and challenge. For the moment, political leaders at both Addis Ababa and Beijing are more or less Sino-optimists in their bilateral relations. However, there is a growing scholarship which viewed Ethio-China relations from Sino-pessimistic and Sino-pragmatist perspectives. This is, without question, imputes of new wave of challenge in Ethio-China relations.

\section{Symmetric or Asymmetric Relations?}

Despite the rhetoric principle of mutual benefit invoked by the political leaders of China and Ethiopia, Ethio-China relations are largely asymmetrical. From the economic point of view, the nature of trade relations between China and Ethiopia is highly imbalance and in favour of China. A study by Gofie and Venkataraman (2015), for instance, putted the negative balance of trade facing Ethiopia as follows:

Ethiopia was reported to have recorded a trade deficit of 2,366 million USD in the fourth quarter of 2012. Balance of Trade for Ethiopia was reported to be 1,556 million from 2006 until 2012, 956.70 during the second quarter of 2007 and 2,366.20 million in the fourth quarter of 2012. (p. 10)

All in all the balance of trade is overwhelmingly negative for Ethiopia while it is totally positive for China. Despite the rhetoric aspiration of reciprocal (mutual) benefits from China-Ethiopian relations, in the area of trade, their relations is asymmetrical. However I'm not rebuffing the growing trade and capital flow in Ethio-China relations rather I'm arguing that one of the contentious issues in their relations is trade imbalance and this in turn further exacerbates the country's problems. I'm not a "fortune-teller" but the already existed asymmetrical relation is foreshadowing "clientelism".

\footnotetext{
${ }^{5}$ Although Ethiopia publicly declared press freedom, it remains ineffectual. Thus, the practices of Ethiopia and China in areas of mass media and other social media are similar, though they purse different medial policy.

${ }^{6}$ While the Western regarded the 2005 general election of Ethiopia as authoritarian and undemocratic, China refrains from critiquing it and continues its relation even with an alarming rate.
} 


\section{West Beijing or South Beijing?}

Since the Cold War period, Chinese official documents unanimously tried to distinguish Chinese engagement, its aid and political cooperation, with Africa from the Soviet Union and the Western countries practice (Liu, 2010). Paradoxically, the reality shows that China shares some practices of the West. In this regard, China unprecedented engagement and an expected openness and optimistic view on the part of African leaders may make China a "West Beijing”. This is true with regard to its provision of credit finance. In Ethiopia, Chinese credit finance is much larger than its foreign direct investment. So, what makes China different from the West is a question, although the rhetoric win-win partnership still prevails. Despite Chinese claims of a truly South partner different from the West, its engagement remains in question.

\section{The Two Facet of Corruption}

It is undeniable fact that corruption has become one of the greatest challenges of Ethiopian development. On one hand, corruption may affect the active engagement of Chinese companies in Ethiopia. On the other hand, the engagement of China in Ethiopia and its aid may further exacerbate administrative mal-practice. Although it is not the deliberate intention of China, some Chinese companies have established patronage system with public officials. In this regard, Gofie and Venkataraman (2015) stated that;

there are significant amount of Chinese products that are imported through contraband trade by rent seeking China's business persons owing largely to the low import tax for items imported from China. This has also led to business practices such as illegally laminating on items imported from Europe the word "Made in China" in order to evade import taxes. This raises the issue of the need for appropriate tariff arrangements that does not allow for illegality but retaining the essentials of market mechanisms. (p. 9)

Thus, corruption both in Ethiopia and Chinese engagement as aggravating factors of administrative mal-practice is another challenge. This may further led to absence of demarcation between legal and illegal, private and public activities and this in turn unintentionally led to patron-client relations.

\section{Different But Similar Ideology}

It seems difficult to situate Chinese and Ethiopia's ideological difference and similarity. On one hand, Ethiopia and China are following different ideological paths (Gedion \& Mathews, 2010). Ethiopia is following politically revolutionary democracy while economically democratic developmental state. Unlike Ethiopia, China is a communist state. Paradoxically, Ethiopia and China are practicing a similar ideology. Both regimes’ are presuming state-led development as a compulsory condition for lasting regime stability. Not surprisingly, both countries dream is similar; Ethiopia prophesies the so-called Ethiopian Renaissance while China's aim is achieving National Rejuvenation.

This similarity further helped by the launch of party-to-party relations. Thus, both countries underline what is known as "the end justifies the means". If both countries are striving for the end by any means, it would be possible to follow any kind of relationship, be it strategic partnership or patronage. But the question is that how the two countries relations can be viewed as strategic partnership. This may suggest that their ideological confusion but similar practice may paradoxically lead them to patronage and clientelism.

\section{Prospects of Ethio-China Relations}

Ethio-China relation is very contentious and complex in its nature. The rise of China provides both the opportunity and challenge for Ethiopia. In this regard, what challenges will face Ethiopia and what 
opportunities Ethiopia will have with its engagement with China may not be seen different from other African counties relations with China. Thus, both the opportunities and challenges of the rise of China in Africa would be determined by each of African countries level of engagement, political will and commitment, united strategy to engage China, having common stance and say (Cheru \& Obi, 2010). The rise of China in Africa would be beneficial for Africans if and only if Africans are in a position to defend their interest, pursuing an alternative strategy to engage China. Moreover, African peoples must be aware of the fact that the official China and African ruling elite relations may lead to the unintentional establishment of a patron-client relations. Thus, examining China-Africa relations from Africans people perspective has paramount importance. In this regard, the case of Ethiopia is not different from that of other African countries. Therefore, there is a need to have a strategic way of engagement aimed at countering the perceived patron-client relations between China and Ethiopia particularly between the two countries ruling party. Falling to adopt countering strategy may be quoted as officially acknowledging "clientelism". Moreover, in the words of Cheru and Obi (2010), it would be also "neo-colonialism by invitation”.

\section{Conclusion}

In this paper, attempt has been made to examine China-Africa relations by taking Ethio-China relations as a case study. For the present moment, China is regarded as a development partner of Ethiopia and other African countries; however there is a sign of a patron-client relation between African ruling elites and China. Thus, Chinese role in Ethiopia and other African countries should not be treated in terms of the rhetoric "altruistic" principles invoked by African ruling elite and Chinese. In this regard, the very China growing presence in Ethiopia should be viewed in light of Ethiopia people's interest, aspiration, and development rather than in terms of party-to-party relations and aid that comes from China. It will be "naïve" to negate the positive role of China in Ethiopia in terms of its involvement in various sectors, building of infrastructures and various projects, growing trade relations, investment and aid; but we should examine whether Chinese presence in Ethiopia as elsewhere in Africa is as a means to an end or an end in itself.

This will depend on the reality and our own interpretation; if the reality is that Chinese growing presence in Africa further exacerbates the intra-inequality and if Chinese aid is being used to further consolidate life presidency and the power of the ruling elite, then it is possible to situate China African relations as a patron-client. Though it seems too difficult to deny the rhetoric of strategic partnership, mutual benefit, win-win cooperation, China-Africa relations is a kind of asymmetrical relationship. Thus, in contemporary Ethio-China, in general China-Africa relations, there is a need on the part of Africa to reconsider their relations with China. The undeniable fact is that there is a manifestation of patronage and "clientelism" in contemporary Africa-China relations indirectly. Thus, African countries should have a countering strategy of patronage and "clientelism”. Falling to do so will mean blessing "clientelism”.

\section{References}

Assogbavi, D. (2010). The role of China in peace and security in Africa. In S. Marks, A. Harneit-Sievers, and S. Naidu (Eds.), Chinese and African perspectives on China in Africa (pp. 194-200). Kampala-Uganda: Pambazuka Press.

Cabestan, J.-P. (2012). China and Ethiopia: Authoritarian affinities and economic cooperation. China Perspectives, 4 , 52-63.

Ciorciari, J. D. (2013). China and Cambodia: Patron and client? International Policy Center Working Paper No. 121.

Corkin, L. (2008). Competition or collaboration? Chinese \& South African transnational companies in Africa. Review of African Political Economy, 35(115), 128-134. 
Cheru, F., \& Obi, C. (Eds.). (2010). The rise of China and India in Africa challenges, opportunities and critical interventions. Uppsala, Sweden: Zed Books Ltd.

Dent, C. M. (Ed.). (2011). China and Africa development relations. New York: Routledge.

Dijk, M. P. V. (Ed.). (2009). The new presence of China in Africa. Netherlands: Amsterdam University Press.

Fantahun, M. (2013). Africa-China relations: Neocolonialism or strategic partnership? Ethiopia as a case analysis (Unpublished Dissertation, Honolulu, Hawaii: Atlantic International University).

Fukuyama, F. (2014). Political order and political decay: From the industrial revolution to the globalization of democracy. Farrar, Straus and Giroux, New York: Macmillan.

Gedion, G., \& Mathews, K. (2010). Ethio-China relations: Challenges and prospects. In S. Marks, A. Harneit-Sievers, and S. Naidu (Eds.), Chinese and African perspectives on China in Africa (pp. 92-107). Kampala-Uganda: Pambazuka Press.

Gofie, M. S., \& Venkataraman, M. (2015). The dynamics of China-Ethiopia trade relations: Economic capacity, balance of trade \& trade regime. Journal of the Global South, 2(8), 1-17.

Kiser, E., \& Sacks, A. (2011). African patrimonialism in historical perspective: Assessing decentralized and privatized tax administration. The Annals of the American Academy of Political and Social Science, 636, 129-149.

Liu, H. F. (2010). China's development cooperation with Africa: Historical and cultural perspective. In F. Cheru and C. Obi (Eds.), The rise of China and India in Africa: Challenges, opportunities and critical interventions (pp. 53-62). Uppsala, Sweden: Zed Books Ltd.

Lejeune, J. (2015). Ruling parties as communities of practice and collective identity in China-Ethiopia relations. Afraso Working Papers, No. 1.

Lumumba-Kasongo, T. (2011). China-Africa relations: A neo-imperialism or a neo-colonialism? A reflection. African and Asian Studies, 10, 234-266.

Lyons, T. (1986). The United States and Ethiopia: The politics of a patron-client relationship. Northeast African Studies, 8(2/3), 53-75.

Seifudein, A. (2012). China in Ethiopia: Diplomacy and economics of Sino-optimism. African Studies Review, 55(1), $143-160$.

Shinn, D. H. (2014). Ethiopia and China: Two former empires connect in the 20th century. Russian Academy of Sciences Institute for African Studies, 13th International Conference of Africanists.

Szeftel, M. (2000). Clientelism, corruption \& catastrophe. Review of African Political Economy, 27(85), 427-441.

Taylor, I. (2006). China's oil diplomacy in Africa. International Affairs, 82(5), 937- 959.

Tegegne, G.-E. (2007). Impacts of Chinese imports and coping strategies of local producers: The case of small-scale foot wear enterprises in Ethiopia. The Journal of Modern African Studies, 45(4), 647-679.

Wang, X. G. (2014). China-Ethiopia economic and political relations post 1991 period (Unpublished Thesis, Addis Ababa University).

Wei, X. D. (2011). A historical review of Ethio-China relations (1952-2011) (Unpublished Thesis, Addis Ababa University).

Yan, H. R., \& Barry, S. (2007). The forest for the trees: Trade, investment and the China-in-Africa discourse. Hong Kong: Hong Kong University of Science and Technology.

Zeleza, P. T. (2008). Dancing with the dragon Africa's courtship with China. The Global South, 2(2), 171-187. 